\title{
Examining Intra-Industry Trade between India \& China: Is India on the Right Track?
}

\author{
Rishi Dwesar'1, Ankit Kesharwani2 ${ }^{*}$ \\ ${ }^{1}$ Department of Marketing \& Strategy, IBS Hyderabad (A Constituent of the ICFAI Foundation of Higher Education), \\ Hyderabad, India \\ ${ }^{2}$ Department of Marketing, Indian Institute of Foreign Trade (IIFT), New Delhi, India \\ Email: rishidwesar@ibsindia.org, *ankit@iift.edu
}

How to cite this paper: Dwesar, R. and Kesharwani, A. (2019) Examining Intra-Industry Trade between India \& China: Is India on the Right Track? Theoretical Economics Letters, 9, 1834-1851. https://doi.org/10.4236/tel.2019.96117

Received: June 28, 2019

Accepted: August 11, 2019

Published: August 14, 2019

Copyright (c) 2019 by author(s) and Scientific Research Publishing Inc. This work is licensed under the Creative Commons Attribution International License (CC BY 4.0).

http://creativecommons.org/licenses/by/4.0/

\begin{abstract}
Massive growth in Industrialization and Gross Domestic Product (GDP) and a stronger relation between India and China have led to an increase in bilateral trade between the two countries. This paper examines the intensity of Intra-Industry Trade (IIT) between India and China using A-Index over a two-decade period (1999 to 2018). Further, the study examines trade patterns of commodities traded between the countries and how have they changed over the years. The study used data of 99 commodities and conducts a decade wise comparison. Recent developments and policy changes on the bilateral trade front between India and China have also been discussed. The research has important implications for policymakers, economists and business involved internal trade.
\end{abstract}

\section{Keywords}

India-China Bilateral Trade, Intra-Industry Trade, India-China Trade Deficit

\section{Introduction}

China and India, the world's most populous country, have seen tremendous economic growth in recent years. China's average GDP growth rate has been more than 9.5 percent from 1989 to 2019, and the country is expected to become the world's largest economy by 2030 [1]. On the other hand, India liberalized its economy in the early 1990s and has witnessed an average growth rate of over 6 percent since then [2]. The Asia-Pacific region has also seen tremendous growth from the late 1980s as the economies within the heterogeneous region have flourished. This can be attributed to the increased regional capital flow, trade, and other forms of economic and political interactions. The region has recognized 
the important role played by Regional Trading Agreements (RTAs) and Free Trade Agreements (FTAs) in trade liberalization and overall development of the countries. The scale of trade has increased after such bilateral trade agreements and has also influenced the volume of production, export, and import in various sectors of the economy. This has also lead to some changes in the nature of international trade and its structure [3]. If successful, the latest proposed trade agreement Regional Comprehensive Economic Partnership (RCEP) between the Association of Southeast Asian Nations (ASEAN) would further enhance bilateral trade in the region. This is likely to make India, China, and other RCEP members to become the world's largest trade block [4]. India and China, in particular, have drawn key attention, as not only they have witnessed high GDP growth rate, but also have a huge economy base, land, and population and play an import role in the regional trade.

Although India and China have been trade partners since centuries, the border dispute among them has influenced the geopolitical relation and the flow of goods. In recent years, trade between the two countries has grown significantly and is expected to reach $\$ 100$ billion by the end of 2019 [3]. However, there is a growing concern for India because the balance of trade is sporadically increasing in favor of China. Over the last two decades (1999 to 2008 and 2009 to 2018), the imports from India to China have increased around 6.9 times, however Indian exports only increased by 3.2 times, leading to increase in the trade deficit of over 11 times. Moreover, there are growing concerns about China dumping products in India, which has lead to the closure of businesses and hampering many industries [5]. It is believed that many imports from China to India are under invoiced, i.e. the actual value of goods imported may be significantly higher. Thus, the growing trade imbalance between India and China is a concern for the country, and India is cautious to join any more regional trade agreements like RCEP. This is because, such trade agreements may further reduce custom duty and import tariffs on the majority of items, further distorting the trade balance [5].

Through this paper, we examine the commodities in which the counties trade, the changes in the pattern of the trade and share of Intra-Industry Trade between the countries. We do this analysis for two decades i.e. from 1999 to 2008 and 2009 to 2018, by making a decade wise comparison. The findings of this study would help policymakers to understand nature and volume to the trade between the two countries and understand its impact on the industries and consumers across both the countries. The paper also contributes to academia by examining the extent to which the trade between the counties is of intra-industry type and how both the counties are placed when it comes to trade of specific commodities.

\section{Background}

Traditionally economists found that countries ventured in international trade 
primary to export goods which were most suited to its own factor endowments and technology while importing the goods which have high factor endowment cost and were least suited to the natural characteristics of the country. As this type of trade involves exports and imports of different type of commodities it is called Inter-Industry Trade [6].

However, lately, it has been established that with increased industrialization, industrial economies increasingly involve in within industry trade, i.e. similar goods or goods broadly belonging to the same industry. The primary reason for this is: reducing sunk costs, enhancing industry specialization, and gets economies of scale [7]. This type of trade is called Intra-Industry Trade (IIT) and involves trade within the same industry.

\subsection{The Theory behind Intra-Industry Trade}

Back in 1817, David Ricardo introduced the Standard Trade Theory and that was when he formulated the popular 'Theory of Comparative Advantage'. Standard trade theory assumes trade involving homogeneous products; hence with perfect competition, there is only Inter-Industry Trade [8]. Ricardo showed that goods are more mobile across international boundaries than other resources (land, labor, and capital) and thus countries would reap more gains from producing whatever best in can and trading that with other nations. Ricardian model of trade showed that countries can take advantage of each other due to differences in the factor of endowments between them, i.e. countries are benefited by better allocation of scarce resources. Thus, according to these theories, countries should export products which are most suited to its factor endowment like natural resources, labor, technology, etc., while importing the goods which have high factor endowment cost and are least suited to the natural characteristics of a particular region or country. Thus, countries primarily trade between goods belonging to different industries. This type of trade is known as Inter-Industry Trade.

However, during the 1970s many international trade researchers found that in many developed industrial nations, a large volume of simultaneous exports and imports was being done between similar kinds of commodities. It was Verdoorn [8] who first observed the formation of custom union among the Benelux Countries which were formed to enhance two-way cross country trade involving similar kind of products. Later, Grubel and Lloyd [9] came out with an index called GL-Index which, which was specifically meant to measure the amount of IIT. In later years, other indexes were introduced to measure IIT which did not share the limitations of GL-Index.

The significance of IIT is not only because of the comparative advantage that lies within a particular country or region, but it also arises as products are differentiated and enormous fixed costs are involved in manufacturing such products. Illustratively, there would be more economic advantage for the industry to produce only cars and minimize the overall cost of production, rather than to 
produce all types of vehicles (motorcycles, vans, trucks, etc.). This illustration can be extended to geographical boundaries also. It other words, it may be of more economic sense to produce one type of product in one country, and second in other, although both belonging to the same industry. Nevertheless, this doesn't mean elements of comparative advantage are not involved. For example, Japan may have a competitive edge in producing electronic items and Germany for high-quality cars. Thus, IIT increases the benefits of trade by better-exploiting economies of scale and bring industry specialization. It focuses on producing a particular type of products or focusing on particular industries. This results in the expansion of world output and reduction or savings of fixed costs.

The nature of trade (Intra or Inter-Industry) depends on the degree of similarities the countries are having between the factors of endowment. As countries become similar, the trade between them will increasingly become intra-industry in character [10]. To better understand some of the differences between characteristics of Inter-Industry Trade vis-à-vis Intra-Industry Trade, a summary adapted from Bernatonyte and Normantienè [11] is given in Figure 1.

To measure Intra-Industry Trade, Grubel and Lloyd [12] came out with the index called the GL-Index. The GL-Index is used widely till date to measure the intensity of IIT for at a specific point of time (a particular year). However, as

\begin{tabular}{|c|c|c|}
\hline Inter-Industry Trade & Point of Difference & Intra-Industry Trade \\
\hline $\begin{array}{l}\text { Different provision of countries } \\
\text { with product factors }\end{array}$ & $\begin{array}{l}\text { Conditions of trade } \\
\text { development }\end{array}$ & $\begin{array}{l}\text { Equal or very similar provision } \\
\text { of countries for production } \\
\text { factors }\end{array}$ \\
\hline $\begin{array}{l}\text { Comparative advantage of } \\
\text { countries in production of } \\
\text { goods }\end{array}$ & Trade reflects & Differentiation of goods \\
\hline $\begin{array}{l}\text { By theory of production factors } \\
\text { proportions }\end{array}$ & Trade explained & By theory of economy of scale \\
\hline $\begin{array}{l}\text { Of owners of comparatively } \\
\text { surplus production factors }\end{array}$ & Trade increased the income & Of owners of all trade factors \\
\hline $\begin{array}{l}\text { Mostly developed, developing } \\
\text { countries of various size }\end{array}$ & Trade within & $\begin{array}{l}\text { Mostly developed countries of } \\
\text { approximately equal size }\end{array}$ \\
\hline $\begin{array}{l}\text { Mainly ready production, } \\
\text { homogeneous goods }\end{array}$ & Structure of goods traded & $\begin{array}{l}\text { Mainly components, parts, } \\
\text { differentiated goods }\end{array}$ \\
\hline $\begin{array}{l}\text { Between large branches, e.g. } \\
\text { manufacturing and agriculture }\end{array}$ & Trade developed & $\begin{array}{l}\text { Within the limits of branches } \\
\text { production manufactures } \\
\text { goods }\end{array}$ \\
\hline $\begin{array}{l}\text { Important social } \\
\text { consequences related to inter- } \\
\text { industry migration of working } \\
\text { force }\end{array}$ & Consequence of trade & Minimal social consequences \\
\hline
\end{tabular}

Source: Bernatonytė and Normantienè [11].

Figure 1. Difference between inter and intra-industry trade. 
Hamilton and Kniest and Brulhart, showed GL-Index is a static measure and can determine IIT only at a specific point in time, but cannot be used to compare values taken from different time periods [13] [14] [15]. Hamilton and Kniest [10] explain, in case of GL-Index "an equiproportionate increase in exports of each country will raise the amount of IIT but will not raise the proportion of it". This is a major drawback of GL-Index, as it cannot be used to compare the proportion of IIT over a period of time.

To overcome the static nature of GL-Index and make index comparable at different time periods Marginal Inter-Industry Trade (MIIT) index were developed. Hamilton and Kniest and Greenaway, Milner et al. initially proposed an index to measure marginal intra-industry trade [10] [15]. However, Hamilton and Kniest's MIIT index is not defined when exports or imports have decreased in a particular year [13].

Bruilhart and Elliott [14] suggested A-Index which is defined in all cases and also takes into consideration the yearly change while calculating the Marginal Intra-Industry Trade. Further, A-Index can be aggregated across industries to reach at an overall level for a particular set of years, which can then be used to compare the trend the over years. Thus, in this study, we examine MIIT between India and China using Bruilhart's A-Index for a period of 20 years. The index calculation has been discussed in the methodology section.

\subsection{Studies on Intra-Industry Trade}

Intra-Industry Trade has been widely researched in the past three decades. Several contributions were made to the theory of IIT and empirical studies were done to find the intensity and determinants of IIT and industry specialization. It was Verdoorn [8] who first observed that the formation of custom union among the Benelux countries enhanced two-way cross country trade involving similar products. Krugman [12] showed that Intra-Industry Trade involves less adjustment cost and concluded: "Intra-Industry Trade poses fewer adjustment problems than inter-industry trade".

Recent studies on IIT have focused on the role of free trade agreements in promoting IIT [16], pattern and growth of IIT across countries and regions [17], the relationship between IIT and demand for child labor [18], determinants of IIT in automotive and electrical appliances sector [19]. Studies have also examined the role of domestic innovation and firm heterogeneity on IIT [20], and the effect of IIT on environment among others [21]. India specific studies on IIT have focused on country-specific factors which influence IIT [22], how trade barriers and multinational involvement leads to change in IIT, and the vertical and horizontal nature of IIT [23].

\subsection{Studies on Cross-Country Trade}

The geographic proximity and vast shared national boundaries make India and China much suited for cross-country trade. The countries also have similar re- 
source pool to some extent, with resources like huge labor pool, iron reserves, etc. Both the countries have seen tremendous economic development in recent years. The India-China trade ties have increased the bilateral trade between them to a significant level. India's economic relation with China dates back to the 1950s when both countries jointly initiated the famous Five Principles of Peaceful Coexistence [24]. Relationship further strengthened in 1988, when Indian Prime Minister, Rajiv Gandhi's visited China. Over the years India and China have broadened bilateral ties in various areas, putting aside the border disputes. Bilateral agreements have been initiated in the form of science and technology cooperation, civil aviation by establishing direct air links, and through cultural exchange programs.

The Chinese economy was decentralized in the 1970s and major economic reforms and structural changes have already taken place in China. By 1999, China became the world's second-largest economy based on GDP at purchasing power parity [25]. The growth of China's economy has been partly due to greater investment effort, setting up numerous Special Economic Zones (SEZs) and an increase in the bilateral trade. Strong export growth has helped China's economy to grow above 9 percent from 2003 onwards. China is currently the world's second-largest recipient for FDI with total FDI inflows crossing the US $\$ 136$ billion in 2018 [26].

India was a latecomer to economic reforms, embarking on the process only in 1991, in the wake of an exceptionally severe balance of payments crisis. The country opted for a systemic shift to a more open economy with greater reliance upon international trade, a larger role for the private sector including foreign investment, and restructuring of the role of government.

The trade volume between India and China has increased from US\$ 1.32 billion in 1999 to US $\$ 800$ billion in 2008, an increase of more than 60 times in 20 years. India has a significant and growing trade deficit with China, as with other major economies in the world. With an increase in bilateral trade with China, the trade deficit has also increased significantly. Moreover, India is always drawn by a fear of being swamped by Chinese imports, especially in cheap electronic goods and appliances category. Majority of industry players in India are repulsive to this and are of opinion that there is no need to give the Chinese a free ride into the domestic markets, as this is creating an adverse situation for Indian exports to China and other courtiers. This is particularly when India and China have been directly competing across several product categories like clothing, leather and textile products [27]. Moreover, businesses and policymakers are concerned with the increased imports of manufactured goods from China. Cheap exports from China have specifically impacted the products manufactured by medium and small scale Indian Industries, which are expensive but of better quality.

Influenced from the above characteristics and an enormous increase in trade over the last two decades, though this paper we analyze the degree to which In- 
dia and China involve in IIT. Moreover, we examine the trend and volume of major commodities traded between the countries over the past two decades. In the later section of this paper, we discuss the trade pattern of various commodities being actively traded between the two countries in recent years, and find the reason of some of the changes in trade pattern and share. The paper provides implications for policymakers, export-import consultants and public at large.

\section{Methodology}

\subsection{Data Set}

Trade data based on the Harmonized Commodity Description and Coding System (HS) was downloaded from the database maintained by the Indian Ministry of Commerce. This HS system is an internationally standardized system of names and numbers to classify traded commodities and came into effect in 1988. The system was developed and maintained by the World Customs Organization (WCO) and is followed by more than 200 member countries [28]. Export and Import data for India and China for all the 99 commodities based on HS was downloaded from the website of Indian Department of Commerce and aggregated in a spreadsheet for a period of 20 years (1999 to 2018). The values were recorded in US\$ million, with dollar value adjusted to the average annual exchange rate prevailing for the particular year.

\subsection{Calculation of Index}

The intensity of MIIT was measured using Weighted A-Index (Brulhart, 1997) for the 20 year period. Following formulas were used to calculate A-Index \& Weighted A-Index:

Calculation of A-Index:

$$
A_{i}=\frac{\left|\Delta X_{i}\right|+\left|\Delta M_{i}\right|-\left|\Delta X_{i}-\Delta M_{i}\right|}{\left|\Delta X_{i}\right|+\left|\Delta M_{i}\right|}
$$

where, $X_{i}$ and $M_{i}$ refer to exports and imports respectively for the year $t$ and $t-$ 1 , for the commodity $i$. Whereas, $\Delta X_{i}=X_{i t}-X_{i, t-1}$ and $\Delta M_{i}=M_{i t}-M_{i, t-1}$.

The value of A-Index varies between 0 and 1 , where, values close to unity indicate trade is of Intra Industry type and values close to 0 indicate trade is of Inter-Industry type.

A-Index can be aggregated across commodities to arrive at Weighted A-Index, by obtaining weighted average across commodities. The weights correspond to the proportion change in the trade of a particular commodity to the proportion of change in the total trade for a given set of years. Thus, weighted A-Index provides aggregated values A-Index across commodities for a given year and provides values of MIIT which can be compared across years, unlike GL-Index.

Calculation of Weighted A-Index

$$
\bar{A} w=\sum_{i=1}^{N} w_{i} A_{i},
$$


where

$$
w_{i}=\frac{\left|\Delta X_{i}\right|+\left|\Delta M_{i}\right|}{\sum_{i=1}^{N}\left(\left|\Delta X_{i}\right|+\left|\Delta M_{i}\right|\right)}
$$

\section{Analysis and Findings}

Values for trade volume and MIIT were calculated and analyzed for the two-decade period. The first decade comprised trade between the countries from 1999 to 2008, and the second decade from 2008 to 2018. The decade wise comparison provided a realistic way to analyze and compare structural trade changes. Also, the year 2008-2009 was chosen to divide the two decades, as the year witnessed the global recession which impacted the export-imports between the counties [29].

As it was not cognizant to analyze all the 99 commodities, top 20 export-import commodities between India and China were identified and used for analysis. This resulted in a total of 30 commodities, which represented at least 85 percent of the total trade between the two countries for a particular year. Decade wise comparison was done to examine the changes in trade patterns over a long period of time.

\subsection{Decade 1 (1999 to 2008)}

The weighted A-Index between Indian and China from 1998 to 2018 ranged from 0.05 to 0.27 ( 5 percent to 27 percent), reveling trade between the two countries is predominantly of inter-industry type. This is not alarming, as previous studies have found that IIT in developing and newly-industrialized countries (NICs) is generally less than 10 percent of their total trade [30]. Second, it can be observed that the A-Index doesn't follow a particular trend, reflecting that trade between India and China is relatively inconsistent. For the first decade, 2004 has the highest level of MIIT (weighted A-Index $=0.24$ ). The value was specifically high when compared to 1999 (weighted A-Index = 0.07), 2002 (weighted A-Index $=0.11$ ) and 2003 (weighed A-Index $=0.13$ ). Refer to Figure 2 and Figure 3.

To understand the factors which affected the level of IIT, commodity-specific changes in the trade volume (weights) and A-Index ratio was analyzed. Mineral fuels (HS 27) which had no IIT in 1999 had an A-Index of 0.83 in 2004. Similarly, Ores (HS 26) represented 3.37 percent of the total trade with an A-Index of 0.06 in 1996, while in 2004 it represented 17.5 percent of the total trade and increased A-Index of 0.14 (Refer, Table 1). Other products for which the IIT increased and had a high share of trade included organic chemicals (HS 29), inorganic chemicals (HS 28) and cotton (HS 2). Also, the total trade increased from US\$1322.44 Million in 1999 to US\$ 6243.46 Million in 2004.

During the decade, the commodities which had the highest share of exports included Ores, Slag \& Ash (HS 26), Cotton (HS 52), Copper (HS 74), etc. While the top three commodities which were imported were Electrical Machinery and 


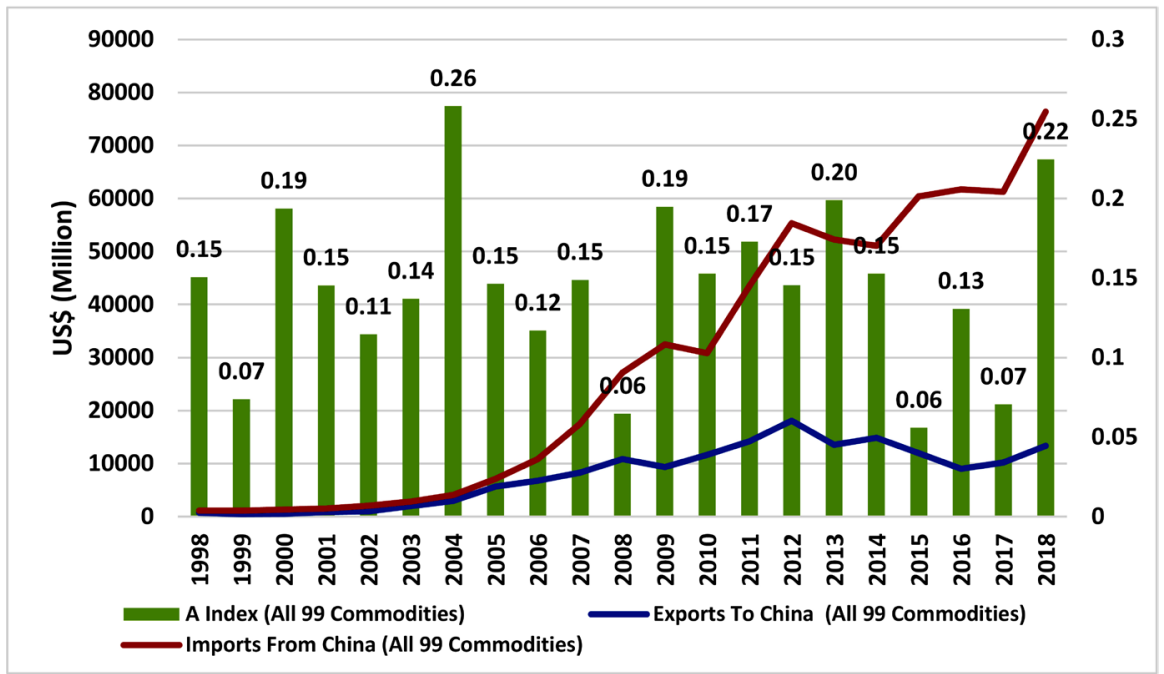

Figure 2. Weighted a-index and exports-imports for all commodities.

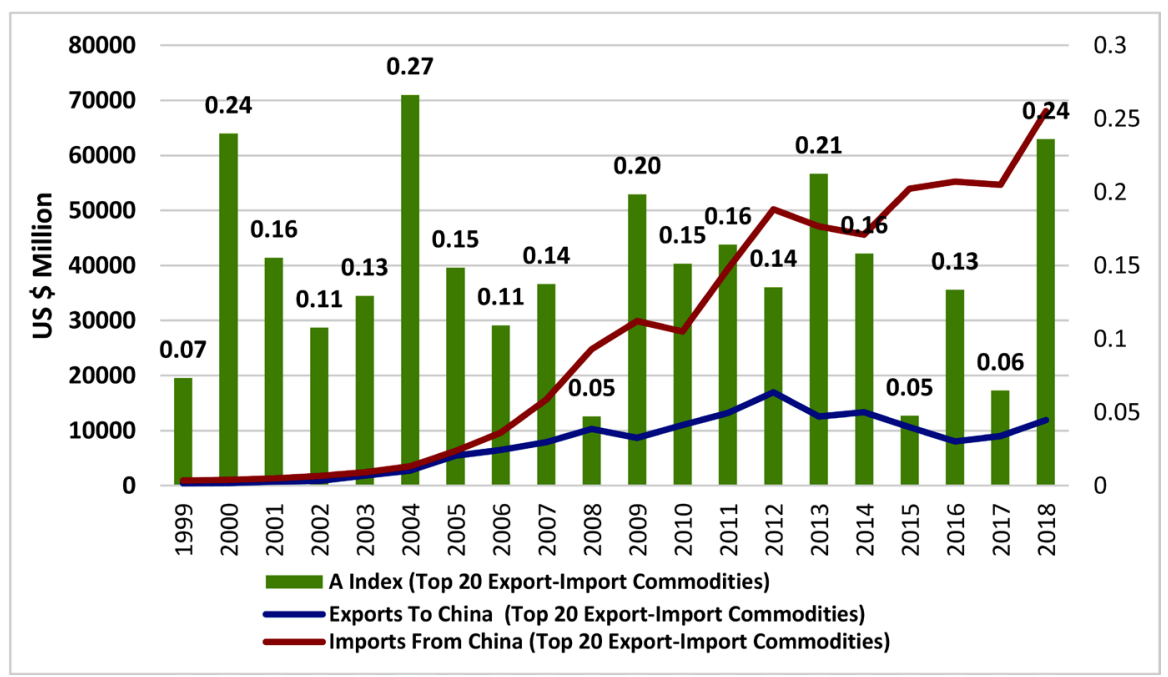

Figure 3. Weighted a-index and exports-imports for top 20 commodities.

Equipment (HS 85) Nuclear Reactors, Boilers, etc. (HS 84) and Organic Chemicals (HS 29). Refer to Figure 4 and Figure 5.

Not only the value of IIT is low, but the industries (commodities) in which both the countries actively trade are very primary in nature. Specifically, India has no commodity in which there is high IIT corresponding to the high share of exports. For example, India's highest share of export aggregated from 1999-2008 is for Ores and Slag (HS 26) which contributed to 49.6 percent of total trade but its weighted A-index is only 0.08 (Refer, Figure 4). Similarly, Iron \& Steel (HS 72) and Cotton (HS 52), which contributed 8 percent and 7.7 percent of exports to China from 1999 to 2008 had a moderately high A-Index of 0.23 and 0.26 respectively. Further, India lost its net exporter position to 2007 onwards for Iron and Steel (HS 72). Considering manufacturing goods which require significant specialization, India only imported such commodities from China, with minimal exports. For example, Electrical Machinery and Equipment (85) and Nuclear 
Table 1. India and China export-import data and a-index 1999-2018 (top 20 export-import commodities).

\begin{tabular}{|c|c|c|c|c|c|c|c|c|c|c|c|c|c|}
\hline \multirow{2}{*}{$\begin{array}{l}\text { HS } \\
\text { Code }\end{array}$} & \multirow[b]{2}{*}{ Commodity } & \multirow{2}{*}{$\begin{array}{c}\text { Rank } \\
\text { (Export, } \\
\text { Import) }\end{array}$} & \multicolumn{4}{|c|}{ Exports (India to China) } & \multicolumn{4}{|c|}{ Imports (China to India) } & \multicolumn{3}{|c|}{ Weighted A Index } \\
\hline & & & $\begin{array}{l}1999 \text { to } \\
2018\end{array}$ & $\begin{array}{c}1999 \text { to } \\
2008\end{array}$ & $\begin{array}{l}2009 \text { to } \\
2018\end{array}$ & $\begin{array}{c}\% \\
\text { Change }\end{array}$ & $\begin{array}{c}1999 \text { to } \\
2018\end{array}$ & $\begin{array}{l}1999 \text { to } \\
2008\end{array}$ & $\begin{array}{l}2009 \text { to } \\
2018\end{array}$ & $\begin{array}{c}\% \\
\text { Change }\end{array}$ & $\begin{array}{c}1999 \text { to } \\
2008\end{array}$ & $\begin{array}{c}2009 \text { to } \\
2018\end{array}$ & $\begin{array}{c}\% \\
\text { Change }\end{array}$ \\
\hline 26 & Ores, Slag \& Ash. & 1,46 & $45,537.3$ & $18,358.1$ & $27,179.2$ & 48.1 & 833.2 & 465.2 & 368.0 & -20.9 & 0.08 & 0.00 & -96.9 \\
\hline 52 & Cotton. & 2,31 & $23,962.9$ & 2837.7 & $21,125.2$ & 644.5 & 2219.2 & 656.4 & 1562.8 & 138.1 & 0.26 & 0.04 & -86.3 \\
\hline 29 & Organic Chemicals. & 4,3 & $12,006.1$ & 2678.8 & 9327.3 & 248.2 & $57,928.1$ & 8412.5 & $49,515.5$ & 488.6 & 0.38 & 0.45 & 17.3 \\
\hline 27 & $\begin{array}{l}\text { Mineral Fuels, Oils, Products of } \\
\text { Distillation. }\end{array}$ & 5,9 & 8188.7 & 395.0 & 7793.7 & 1873.0 & $12,733.5$ & 5389.4 & 7344.1 & 36.3 & 0.26 & 0.41 & 58.3 \\
\hline 72 & Iron \& Steel. & 6,6 & 6501.3 & 2948.0 & 3553.3 & 20.5 & $19,546.1$ & 2653.9 & $16,892.2$ & 536.5 & 0.23 & 0.27 & 15.8 \\
\hline 25 & Salt; Sulphur; Cement \& Stone, etc. & 8,38 & 6105.8 & 1019.7 & 5086.1 & 398.8 & 1469.0 & 512.8 & 956.3 & 86.5 & 0.31 & 0.20 & -34.8 \\
\hline 84 & Nuclear Reactors, Boilers etc. & 9,2 & 5128.2 & 765.8 & 4362.4 & 469.7 & $107,096.1$ & 12747.1 & $94,349.0$ & 640.2 & 0.16 & 0.08 & -52.6 \\
\hline 85 & $\begin{array}{l}\text { Electrical Equipment, Television, } \\
\text { Sound Recorders etc. }\end{array}$ & 10,1 & 3242.8 & 330.6 & 2912.3 & 780.9 & $180,034.7$ & 18965.7 & $161,069.0$ & 749.3 & 0.09 & 0.11 & 27.4 \\
\hline 15 & Animal Or Vegetable Fats \& Oils. & 11,79 & 3125.5 & 291.3 & 2834.2 & 873.1 & 94.0 & 7.0 & 87.0 & 1135.4 & 0.08 & 0.08 & 3.5 \\
\hline 28 & $\begin{array}{l}\text { Inorganic, Organic Compounds, } \\
\text { Precious Metals etc. }\end{array}$ & 12,14 & 2708.6 & 1287.6 & 1421.0 & 10.4 & 7714.6 & 1457.8 & 6256.8 & 329.2 & 0.51 & 0.54 & 5.5 \\
\hline 3 & $\begin{array}{l}\text { Fish \& Crustaceans, Molluscs \& } \\
\text { Aquatic Invertebrates. }\end{array}$ & 13,95 & 2648.9 & 989.2 & 1659.8 & 67.8 & 3.3 & 1.2 & 2.1 & 70.8 & 0.00 & 0.00 & 7.3 \\
\hline 71 & $\begin{array}{l}\text { Pearls, Precious or Semiprecious } \\
\text { Stones etc. }\end{array}$ & 14,13 & 2321.5 & 97.5 & 2224.0 & 2182.2 & 7755.5 & 1075.3 & 6680.2 & 521.3 & 0.15 & 0.26 & 70.2 \\
\hline 90 & $\begin{array}{l}\text { Optical, Photographic, Precision, } \\
\text { Medical Instruments. }\end{array}$ & 16,10 & 1420.4 & 216.1 & 1204.4 & 457.5 & 11148.9 & 988.7 & $10,160.2$ & 927.6 & 0.29 & 0.24 & -16.9 \\
\hline 38 & Miscellaneous Chemical Products. & 17,15 & 1278.9 & 214.0 & 1064.9 & 397.7 & 7298.2 & 597.8 & 6700.5 & 1020.9 & 0.39 & 0.09 & -76.0 \\
\hline 13 & Lac; Gums, Resins etc. & 18,71 & 1264.1 & 179.8 & 1084.4 & 503.2 & 159.4 & 9.6 & 149.9 & 1467.7 & 0.24 & 0.06 & -73.5 \\
\hline 41 & Raw Hides, Skins \& Leather. & 19,62 & 1186.8 & 227.7 & 959.2 & 321.3 & 316.7 & 73.1 & 243.7 & 233.5 & 0.49 & 0.36 & -25.7 \\
\hline 32 & Tanning \& Dyeing Extracts etc. & 20,22 & 1185.3 & 245.0 & 940.3 & 283.8 & 3727.2 & 513.3 & 3213.9 & 526.1 & 0.45 & 0.32 & -28.9 \\
\hline 87 & Vehicles other than Railway. & 24,12 & 853.3 & 84.8 & 768.5 & 806.5 & $10,092.0$ & 659.6 & 9432.5 & 1330.1 & 0.11 & 0.35 & 213.5 \\
\hline 73 & Articles of Iron or Steel. & 26,7 & 661.9 & 71.7 & 590.3 & 723.5 & $15,162.8$ & 2562.5 & $12,600.3$ & 391.7 & 0.06 & 0.15 & 143.2 \\
\hline 76 & Aluminum \& Articles. & 33,17 & 493.8 & 104.2 & 389.6 & 274.1 & 5585.3 & 555.9 & 5029.4 & 804.7 & 0.27 & 0.20 & -26.1 \\
\hline 50 & Silk. & 48,19 & 135.6 & 30.0 & 105.5 & 251.5 & 4902.0 & 2223.3 & 2678.7 & 20.5 & 0.05 & 0.05 & 5.7 \\
\hline 94 & Furniture; Bedding, Mattresses etc. & 49,16 & 129.1 & 4.3 & 124.8 & 2815.4 & 7058.2 & 656.0 & 6402.2 & 875.9 & 0.02 & 0.16 & 633.8 \\
\hline 59 & $\begin{array}{l}\text { Impregnated, Coated or Laminated } \\
\text { Textile Fabrics. }\end{array}$ & 50,18 & 121.9 & 7.1 & 114.8 & 1516.2 & 5237.8 & 949.2 & 4288.6 & 351.8 & 0.02 & 0.12 & 665.8 \\
\hline 89 & Ships, Boats \& Floating Structures. & 57,11 & 82.1 & 45.9 & 36.2 & -21.3 & $10,602.8$ & 648.0 & 9954.9 & 1436.3 & 0.15 & 0.00 & -100.0 \\
\hline 98 & Project Goods; Some Special Uses. & 58,4 & 74.1 & 28.9 & 45.2 & 56.5 & $22,379.7$ & 1148.5 & $21,231.2$ & 1748.7 & 0.05 & 0.01 & -84.0 \\
\hline 69 & Ceramic Products. & 67,20 & 53.2 & 11.7 & 41.6 & 256.5 & 4808.6 & 712.2 & 4096.4 & 475.2 & 0.08 & 0.07 & -4.0 \\
\hline 31 & Fertilizers. & 83,5 & 6.5 & 2.3 & 4.2 & 79.0 & $20,455.6$ & 1356.8 & $19,098.8$ & 1307.6 & 0.05 & 0.00 & -96.3 \\
\hline & Total & & $152,759.6$ & $37,043.8$ & $115,715.7$ & 212.4 & $542,946.2$ & $67,732.7$ & $475,213.5$ & 601.6 & 0.14 & 0.15 & 6.2 \\
\hline
\end{tabular}




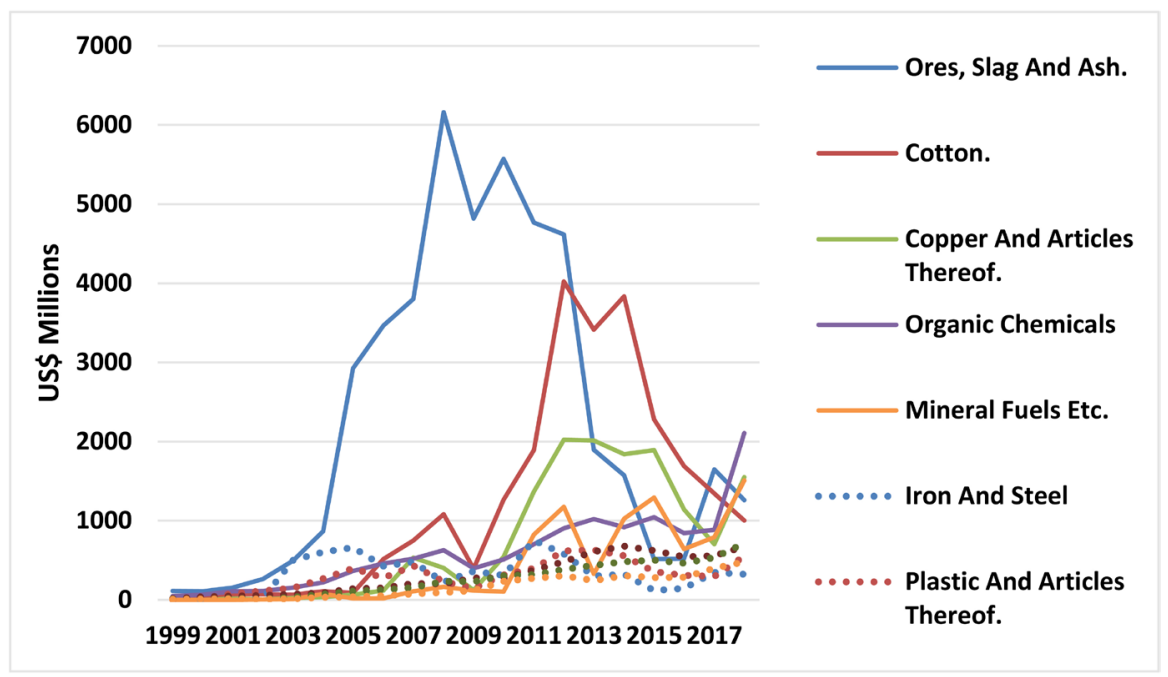

Figure 4. Yearly export pattern from 1999 to 2018 for top 10 commodities.

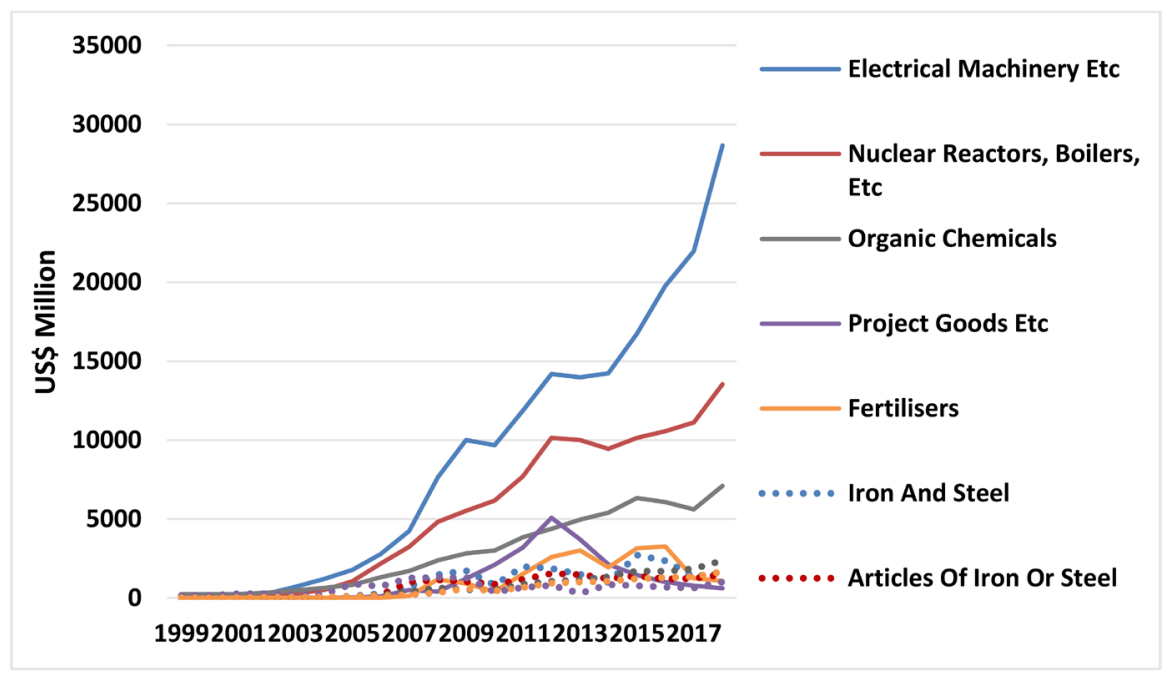

Figure 5. Yearly import pattern from 1999 to 2018 for top 10 commodities.

Reactors and Boilers (84) contributed 28 percent and 18.8 percent respectively of total imports from China from 1999 to 2008 . While on the export side, the share of these two commodities was less than 2 percent during the same period. Refer to Table 1.

From 2005 to 2008, the trade deficit between the countries increased significantly (Refer, Figure 2). In 2005, India's export (import) stood at US $\$ 5615.8$ (US \$7098.0) million and increased to US\$10,384 (US \$27,116.0) million by 2008, though exports increased by 1.92 times, imports increased by 3.8 times, exponentially increasing the trade deficit by around 11 times. In value terms, the trade deficit increased from US\$ 1482 million to US \$16281 million during the decade. Although, India was a net importer from China during these years, such increase in trade imbalance puts India in an unfavorable situation. Next, we examine the trade patterns for specific commodities during this decade.

Fertilizers (HS 31) had a marginal share of imports in 2005 and increased by 
65 times in the year 2008. The reason for this exponential increase is due to government policies and intervention. India is primarily an agrarian economy, inputs like fertilizers, irrigation water and electricity has significant demand. Also, to cater to the growing need of staples and to keep inflation under control, food grains production is the nation's top priority. Since not all farmers can afford fertilizers at all times, government subsidies the fertilizers to ensure they are available at lower costs. The share of fertilizer subsidy increased significantly in the post-reforms period from Rs. 43 billion crores in 1990-1991 (approximately US $\$ 1$ billion) to Rs. 75,849 crore (approximately US $\$ 19$ billion) in 2008-2009. As a percentage of GDP, this represents an increase from 0.85 percent in 1990-1991 to 1.52 percent in 2008-2009 [31]. Further, fertilizer subsidy has attracted a lot of attention of policymakers, researchers, and politicians in the recent past [32]. China being the world's largest producer of potash-one of the key fertilizer used in India-fertilizers are one of the key commodity imported from China.

The second commodity for which India's import has increased is Iron and Steel (HS 72). Iron and steel were one of the most traded commodities between the two countries. India was a net exporter of Iron and Steel to China till 2006 and its exports increased massively till 2005. However, 2005 onwards India's share in exports have decreased (Refer, Figure 4). From 2005 to 2008 Iron and Steel imports have increased by 450 percent, whereas the exports have fallen by 35 percent. Primarily policy changes have been responsible for this. To protect its domestic market, the Indian government imposed 5 percent duty on iron and steel. India had also received a lot of criticism from the international community and WTO for imposing this 5\% duty on iron and steel imports but this has been deemed necessary to protect the local industry from the influx of cheap steel varieties from China. This import duty has made iron and steel exports from India to China less attractive, but imports have been growing due to increasing domestic demand.

Imports in other commodities like articles of Iron and Steel (HS 73), Project goods and goods of special uses (HS 98), vehicles other than railway rolling stock (HS 87), paper and paper pulp have also increased significantly due to increased domestic demand and china having competitive edge in production of their goods. On the export side, India's export of mineral fuel and mineral oils (HS 27) and copper and other articles of copper (HS 74) have increased significantly. However, India has not been able to achieve a competitive advantage in the global export market and this makes Indian goods exports less attractive. Further, India primarily exports raw materials and primary goods to China, which are labor-intensive and have minimal value-added revenues. On the other hand, India imports goods which are more technology-oriented and specialized in nature. Not only this, relative to India, China is much more integrated with the world economy and its share of global exports is nearly six times that of India. Share of China's export to industrial countries, as a percentage of total exports, 
have increased from 35 percent in 1990 to 52 percent in 2006, on the other side India has experienced an opposite trend where its share has declined from 55 percent in 1990 to 44 percent in 2006 [27]. This shift from industrial nations to developing nations reflects the declining competitiveness and shift towards primary goods and inputs of Indian exports. Further, the competitiveness of Indian exports as compared to China, as well as the world is relatively much lower. For example, China ranks number one for four categories of goods, whereas India's minimum rank is five and seven in clothing and textile respectively. Also, the share of India's exports to the world as compared to China is relatively much lower (Refer, Table 1). Moreover, the Indian trade basket (exports) with China is highly concentrated. Our findings support the findings of Nag and Chatterjee [33], that only the top 11 commodities constitute more than 70 percent of the trade. However, India's imports from China are much widespread across different commodities and more than top 40 commodities on an average aggregate together contribute to 70 percent of trade. Thus, India is much more dependent on Chinese imports in various sectors.

\subsection{Decade 2 (2009 to 2018)}

Though the trade significantly increased in the year 2009 to 2018, the proportion of IIT was almost similar to the previous decade. The A-Index for the year 2009 to 2018 ranges from 0.06 to 0.22 ( 6 to 22 percent). The IIT values do not follow a particular pattern, reflecting that the trade between the two countries is not consistent. Further, we analyzed for which commodities the IIT changed over the decade. Examining these changes would reveal if the trade between the two countries is becoming more industrialized or is still primary in nature. To understand the change in IIT trade patterns, we specifically analyze the change in IIT for all the top 20 export-import commodities. It is interesting to note that for many commodities the proportion of IIT has increased or decreased significantly. The highest increase in IIT was for Textile Fabrics (HS 59) [IIT increase = 665\%] and Furniture, Bedding, etc. (HS 94) [IIT increase $=633 \%$ ), however, this product had very low trade volume. Other commodities where IIT increased were Vehicles (HS 87) [IIT increase $=213 \%$ ] and Articles of Iron and Steel (HS 73) [IIT increase $=143 \%$ ]. However, all these four commodities represented less than 5 percent of the total trade volume. Commodities which represented significant trade volume and for which IIT also increased include Electrical Machinery \& Equipment (HS 85) [IIT increase $=27.4 \%$ ) and Organic Chemicals (HS 29) [IIT increase $=17.3 \%]$. The Electrical Machinery \& Equipment share was around $28 \%$ of the total trade, whereas the share of Organic Chemicals was $10 \%$. The highest A-Index was recorded for the year 2018 (A-Index $=0.22$ ), which was much higher than in 2017 (A-Index $=0.22)$. While analyzing the reason for this change we found that Organic Chemicals (HS 29), Plastic Articles (HS 39) and Mineral Fuels led to this change.

While comparing the increase in trade volume for the decade, the imports 
from China to India grew by a whopping 7 times. On the contrary, the export from India to China grew only three times, increasing the trade deficit by 11.7 times. The commodities for which exports to China increased manifold includes Furniture, Bedding, etc. (HS 94), Natural or Cultured Pearls (HS 71), Mineral Fuels and Mineral Oils (HS 27), Copper and Copper Articles (HS 74), Cotton (HS 52), etc. On the other side, apart from Ships, Boats \& Floating Structures (HS 29), for no other commodity, there was a decrease in exports. On the import side, commodities for which the inflow increased maximum where Project Goods (HS 98), Fertilizers (HS 31), Ships, Boats \& Floating Structures (HS 29), Lac, Gums and Resign (HS 13), Animal and Vegetable Fats (HS 15), Miscellaneous Chemical Products (HS 38). However, trade data for the year 2018-19 (beyond the time period of this study) reveals that for the first time in history, India decreased its trade deficit with China. The primary reason for the same was an increase in the export of Cotton and a decrease in imports of electronic items.

\subsection{Key Difference in Decade 1 (1998 to 2008) and Decade 2 (2009 to 2018)}

Decade wise comparison reveals that Indian exports to China became slightly broad in nature and were not focused on three primary commodities. For example Ores, Slag and Ash (HS 26) contributed more than 46 percent of the total trade in first decade, but its share decreased to 21 percent in the second decade. On the other hand, proportion of trade of Mineral Fuels (HS 27), Nuclear Reactor (HS 84), Machinery Equipment (HS 85) increased significantly. Whereas, proportion of imports from China drastically reduced for Mineral Fuels (HS 27), Silk (HS 50), Fabric (HS 59), etc. On the intra-industry trade side, the trade increased for Ships, Boats (HS 89), Miscellaneous products (HS 38), Copper (HS 74) and decreased for Pearls (HS 71), Plastic (HS 39), etc. The exports increased by 215 percent whereas the imports increased by 587 percent from decade 1 to decade 2 , increasing the trade deficit sporadically.

\section{Discussion}

Contribution of China and India in global and Asian trade has been increasing in recent years. In this paper, we examined the nature and volume of bilateral trade between India and China. Motivated by IIT theory, the objective of this paper was to understand if India and China have started trade in specialized products, best leveraging the factors of endowment. As India and China are increasing becoming industrialized, it was expected that the intra-industry trade would have increased over the years.

Nevertheless, we find that India and China are still predominantly trading in different commodities and are majorly involved in Inter-Industry Trade. Further, the majority of exports from India to China are primary in nature, which includes predominantly includes raw-materials and some semi-finished goods. 
The commodities majorly exported by India to China included Ores, Slag, Ash, Organic Chemicals, Iron and Steel, Cotton etc. China's exports to India included primary products like Organic Chemicals, Iron and Steel, Silk; but also secondary and manufactured goods like Electrical Machinery, Nuclear Reactors, and Boilers, etc. Moreover, the proportion of intra-industry trade over the two decades was inconsistent. Studies have shown that as countries develop and become more industrialized the volume and proportion of IIT increases. However, in the context of India and China, though the intra-industry trade increased along with an increase in overall trade, the proportion has not increased. Moreover, the proportion of Intra Industry Trade was inconsistent, where some year had more than 20 percent of the trade as inter-industry years, while other years had less than 10 percent.

Another area of concern is the growing trade deficit between India and China. The trade deficit has specifically increased from 2014, as the exports from India to China decreased while the exports have increased. For the four year period from 2014 to 2018, the trade deficit increased by 1.7 times. The growing trade balance is a cause of concern for policymakers and is much debated at an international level. For example, though India was keen to join RECP initially, lately there is resistance as this will lead to further reduction of import tariffs making the situation even worst [34]. However, economists feel not joining RECP would limit India's trade with its South Asian countries and increase the role of China. Further, realizing that India needs to increase its share of exports to China, more ways in which trade between the two counties can be increased are being sought. The recent US-China trade war has made exports of more than 150 items more favorable due to increased tariff China has imposed on the US [35]. Interestingly, the trade deficit between India and China decreased for the first time in the year 2018-2019 [36]. Given that trade data for this year not public yet, we could not include this year in our analysis. The key reason for the decrease in the deficit was a lesser import of electronic items. Although there is global pressure on China to stabilize its trade imbalance with its neighbors like India, experts opine that the decrease in deficit maybe just an eye-wash. This is so because; during the same year, the export of similar times increased significantly from Hong Kong, suggesting that China may have routed its exports through Hong Kong. However, this reveals the desperateness on both the sides to sell its products in exchange of dollars.

The paper also focused on the nature of commodities which are treaded between the countries, and the extent to which import and export of these have changed. This was important to understand the nature of trade and IIT between the two countries. The analysis found that in recent years India's export of Furniture, Bedding, Mattress, Pearls and Semiprecious Stones, Mineral Fuels, and Copper have increased sporadically. However, the items which contribute the majority of share to export include Ores, Slag, Ash, Cotton, and Copper. However, India still does import finished goods from China the majority of being 
Electrical Equipment, Nuclear Reactors, etc. Although India understands the need to build internal competence to reduce reliance on exports for manufactured goods and the incumbent government has introduced initiates like "Made in India", India is still an import lead when it comes to manufactured products. The trade deficit between India and China reduced by more than US $\$ 10$ billion in the year 2019, as India got access to export Sugar, Rice, Pharma, Grapes, Fish Meal, Fish Oil, rapeseed meal, and tobacco to China [36]. Nevertheless, India needs to build its competitiveness in industrial products.

In years to come, the pattern of Indo-China trade will depend on several factors. These include economic growth trajectories of the two countries, government policies, negotiations with WTO, external economic outlook, the competitiveness of exports of the two countries in each other's markets and the "effectiveness" of tariff and non-tariff barriers in curbing the exports. Moreover, the specialization between industries and the commodities traded between the two countries should increase. Given that India and China are set to become the world's largest economies in next few years, enhancing trade relationship which enables both the countries at a global level would help the countries in the long run. Moreover, the global trade environment would also play a major role in the relationship and the bilateral trade relationship between the two countries.

\section{Conflicts of Interest}

The authors declare no conflicts of interest regarding the publication of this paper.

\section{References}

[1] Zilber, A. (2019) The United States Will Drop to Become the World's THIRD Biggest Economy behind China and India by 2030, New Financial Rankings Suggest. Daily Mail.

https://www.dailymail.co.uk/news/article-6575793/China-worlds-largest-economy2030-India-surpass-U-S.html

[2] The Economic Times (2019) India-China Trade to Cross USD 100 Billion This Year: Envoy.

https://economictimes.indiatimes.com/news/economy/foreign-trade/india-china-tr ade-to-cross-usd-100-billion-this-year-envoy/articleshow/69676323.cms

[3] Li, C., Wang, J. and Whalley, J. (2017) China's Regional and Bilateral Trade Agreements. The Economies of China and India Cooperation and Conflict, 1, 175-194. https://doi.org/10.1142/9789813220713_0007

[4] Waghmare, A. and Chakraborty, S. (2019) How Chinese Goods Are Choking Indian Industry and Economy: The Hard Numbers. Business Standard. https://www.business-standard.com/article/economy-policy/how-chinese-goods-are -choking-indian-industry-and-economy-the-hard-numbers-118072800622_1.html

[5] Helleiner, G.K. (1973) Manufactured Exports from Less-Developed Countries and Multinational Firms. The Economic Journal, 83, 21-47.

https://doi.org/10.2307/2231098 
[6] Grubel, H.G. and Lloyd, P.J. (1975) Intra-Industry Trade. The Theory and Measurement of International Trade in Differentiated Products. Macmillan, London.

[7] Ruffin, R.J. (1999) The Nature and Significance of Intra-Industry Trade. Economic and Financial Review. Federal Reserve Bank of Dallas, 4, 2-16.

[8] Verdoorn, P.J. (1960) The Intra-Bloc Trade of Benelux. In: Robinson, E.A.G., Ed., Economic Consequences of the Size of Nations. International Economic Association Conference Volumes, Palgrave Macmillan, London, 291-329. https://doi.org/10.1007/978-1-349-15210-0_19

[9] Grubel, H.G. and Lloyd, P.J. (1971) The Empirical Measurement of Intra-industry Trade. Economic Record, 47, 494-517.

[10] Krugman, P (1981) Intra Industry Specialization and the Gains from Trade. Journal of Political Economy, 89, 959-974. https://doi.org/10.1086/261015

[11] Hamilton, C. and Kniest, P. (1991) Trade Liberalization, Structural Adjustment and Intra-Industry Trade: A Note. Weltwirtschaftliches Archiv, 127, 356-367. https://doi.org/10.1007/BF02707991

[12] Bernatonytė, D. and Normantienè, A. (2007) Estimation of Importance of Intra-Industry Trade. Inžineriné ekonomika, 3, 25-34.

[13] Brülhart, M. (1994) Marginal Intra-Industry Trade: Measurement and Relevance for the Pattern of Industrial Adjustment. Review of World Economics, 130, 600-613. https://doi.org/10.1007/BF02707615

[14] Brülhart, M. and Elliott, R. (2002) Labour-Market Effects of Intra-Industry Trade: Evidence for the United Kingdom. Weltwirtschaftliches Archiv, 138, 207-228. https://doi.org/10.1007/BF02707742

[15] Greenaway, D. and Milner, C.R. (1993) Trade and Industrial Policy in Developing Countries. Macmillan, London. https://doi.org/10.1007/978-1-349-22782-2

[16] Ramakrishnan, A. and Varma, P. (2014) Do Free Trade Agreements Promote Intra-Industry Trade? The Case of India and Its FTAs. International Journal of Trade and Global Markets, 7, 129-144. https://doi.org/10.1504/IJTGM.2014.062855

[17] Kumar, S., and Ahmed, S. (2014) Growth and Pattern of Intra-Industry Trade between India and Bangladesh: 1975-2010. The Journal of International Economic Policy, 2, 21-30.

[18] Estevez, K., and Levy, T. (2014) Intra-Industry Trade and the Demand for Child Labor. International Journal of Economic Theory, 10, 275-294. https://doi.org/10.1111/ijet.12040

[19] Salim, R., Islam, A. and Bloch, H. (2018) Patterns and Determinants of Intra-Industry Trade in Southeast Asia: Evidence from the Automotive and Electrical Appliances Sectors. The Singapore Economic Review, 63, 647-665. https://doi.org/10.1142/S0217590815500836

[20] Crescenzi, R., Gagliardi, L. and Iammarino, S. (2015) Foreign Multinationals and Domestic Innovation: Intra-Industry Effects and Firm Heterogeneity. Research Policy, 44, 596-609. https://doi.org/10.1016/j.respol.2014.12.009

[21] Dasgupta, P. and Mukhopadhyay, K. (2018) Pollution Haven Hypothesis and India's Intra-Industry Trade: An Analysis. International Journal of Innovation and Sustainable Development, 12, 287-307. https://doi.org/10.1504/IJISD.2018.091538

[22] Veeramani, C. (2002) Intra-Industry Trade of India: Trends and Country-Specific Factors. Weltwirtschaftliches Archiv, 138, 509-533. https://doi.org/10.1007/BF02707952

[23] Srivastava, A. and Medury, Y. (2011) An Overview of India's Intra-Industry Trade. 
Asia Pacific Business Review, 7, 153-160. https://doi.org/10.1177/097324701100700112

[24] Jiabao, W. (2004) Carrying forward the Five Principles of Peaceful Coexistence in the Promotion of Peace and Development. Chinese Journal of International Law, 3, 363-370. https://doi.org/10.1093/oxfordjournals.cjilaw.a000522

[25] Congressional Research Service (CRS) (2019) China's Economic Rise: History, Trends, Challenges, and Implications for the United States. https://fas.org/sgp/crs/row/RL33534.pdf

[26] United Nations Conference on Trade and Development (2018) World Investment Report. https://unctad.org/en/PublicationsLibrary/wir2018_overview_en.pdf

[27] Quresh, M.S. and Wav, G. (2008) Trade Expansion of China and India: Threat or Opportunity? The World Economy, 31, 1327-1350. https://doi.org/10.1111/j.1467-9701.2008.01131.x

[28] WCO (2019) What Is the Harmonized System (HS)? http://www.wcoomd.org/en/topics/nomenclature/overview/what-is-the-harmonize d-system.aspx

[29] Siddiqui, K. (2009) Financial Crisis and Its Impact on the Economies of China and India. Research in Applied Economics, 1, 1-28. https://doi.org/10.5296/rae.v1i1.183 http://eprints.hud.ac.uk/id/eprint/5722/

[30] Tharakan, P.M. (1984) Intra-Industry Trade between the Industrial Countries and the Developing World. European Economic Review, 26, 213-227. https://doi.org/10.1016/0014-2921(84)90032-1

[31] Sharma, V.P. and Thaker, H. (2009) Fertilizer Subsidy in India: Who Are the Beneficiaries? Working Paper, Indian Institute of Management, Ahmadabad.

[32] Parija, P. and Pradhan, B. (2009) Fertilizer Imports by India May Decline, Aiding China. Bloomberg.

[33] Nag, B. and Chaterjee R. (2009) Bilateral Trade and Investments between India and China: Measuring Relative Competitiveness in Each other's Market. Foreign Trade Review, 44, 33-59. https://doi.org/10.1177/0015732515090202

[34] Whye, L.K. (2019) Will India Join the Regional Economic Comprehensive Partnership? ANI News.

https://www.aninews.in/news/world/others/will-india-join-the-regional-economiccomprehensive-partnership20190624114146/

[35] Shruti, S. (2019) India Plans to Offer Incentives to Companies Moving From China. Bloomberg Quint.

https://www.bloombergquint.com/global-economics/india-plans-to-offer-incentives -to-companies-moving-from-china

[36] Dhillon, D. (2019) India's Trade Deficit with China Just Fell for the First Time in Years-But There Could Be a Catch. Business Insider.

https://www.businessinsider.in/heres-why-indias-trade-deficit-with-china-has-falle n/articleshow/68884483.cms 